\title{
Forest restoration and hydrological parameters effects on soil water conditions: a structural equation modelling approach
}

\section{Restauração florestal e os efeitos dos parâmetros hidrológicos nas condições hídricas do solo: uma abordagem usando modelos de equações estruturais}

\author{
Débora Bessi ${ }^{1}$, Marcel Okamoto Tanaka ${ }^{1}$, Lara Aranha da Costa ${ }^{2}$, Carina Julia Pensa Correa ${ }^{2}$, Kelly Cristina Tonello \\ ${ }^{1}$ Universidade Federal de São Carlos - UFSCAR, São Carlos, SP, Brasil \\ ${ }^{2}$ Universidade Federal de São Carlos - UFSCAR, Sorocaba, SP, Brasil \\ E-mails: debora.bessi@gmail.com (DB), marcel@ufscar.br (MOT), lara.adc@gmail.com (LAC), carinapensa@gmail.com (CJPC), \\ kellytonello@yahoo.com (KCT)
}

Received: March 27, 2018 - Revised: June 20, 2018 - Accepted: Aug 07, 2018

\begin{abstract}
Although the effects of land use changes on hydrological functioning are widely addressed, issues such as which components of the hydrological system are affected, how and on what time scales are still poorly understood. In this context, we evaluated whether forest restoration improves soil water conditions in a Cerrado area, and whether the combined effects of forest structure and hydrological variables influence soil attributes. For this, we monitored three areas in different stages of natural succession over seven months, and evaluated vegetation structure indicators, hydrological indicators and soil indicators. Vegetation structure variables were analyzed with Principal Components Analysis, and to evaluate the direct and indirect effects among the variables we used structural equations modelling. Each successional stage differed in relation to forest structure, affecting the hydrological processes and causing the improvement of soil attributes with forest development. In the initial stage, throughfall was higher due to the more open vegetation, and the soil was more resistant to penetration. With the development of the vegetation, stemflow and interception also increased. As a result of the structural and hydrological changes, the model indicated that soil moisture was influenced directly by throughfall and stemflow, as well as by soil resistance to penetration and infiltration rates, and indirectly by forest structure, which influenced these variables, except infiltration rates. These results suggest that hydrological variables can be good indicators of forest restoration monitoring, providing a direct link to changes in soil conditions.
\end{abstract}

Keywords: Forest hydrology; Soil moisture; Resistance to penetration.

\section{RESUMO}

Embora os efeitos das mudanças de uso da terra sobre o funcionamento hidrológico sejam amplamente abordados, questões como quais componentes do sistema hidrológico são afetados, de que maneira e sobre quais escalas de tempo ainda são pouco compreendidas. Nesse contexto, avaliamos se restauração florestal melhora as condições hídricas do solo em uma área de Cerrado, e se os efeitos combinados da estrutura florestal e das variáveis hidrológicas influenciam nos atributos do solo. Para isso, monitoramos três áreas em diferentes estágios de sucessão natural ao longo de sete meses, tendo sido avaliados indicadores de estrutura da vegetação, indicadores hidrológicos e indicadores do solo. As variáveis de estrutura da vegetação foram analisadas segundo Análise de Componentes Principais, e para explicar os efeitos diretos e indiretos entre as variáveis foi utilizada modelagem de equações estruturais. Cada estágio sucessional diferiu em relação à estrutura da vegetação, afetando os processos hidrológicos e ocasionando a melhoria dos atributos do solo com o desenvolvimento da floresta. No estágio inicial a precipitação interna foi mais elevada devido à vegetação mais aberta, e o solo apresentou maior resistência à penetração. Com o desenvolvimento da vegetação, o escoamento pelo tronco e a interceptação também aumentaram. Em decorrência das mudanças estruturais e hidrológicas, o modelo indicou que a umidade do solo foi diretamente influenciada pela precipitação interna e escoamento pelo tronco, assim como pela resistência à penetração e taxas de infiltração do solo, e indiretamente pela estrutura, que influenciou estas variáveis, com exceção das taxas de infiltração. Estes resultados sugerem que as variáveis hidrológicas podem ser bons indicadores para o monitoramento de florestas restauradas, provendo uma ligação direta com as mudanças nas condições dos solos.

Palavras-chaves: Hidrologia florestal; Umidade do solo; Resistência à penetração. 


\section{INTRODUCTION}

Forest-water relationships has long studied worldwide (BOSCH; HEWLETT, 1982; FAO, 2013; LEVIA; GERMER, 2015; ZHANG et al., 2017; LUO et al., 2018; BROGNA et al., 2018). Forests influence the hydrological cycle and, consequently, the water resources. From the perspective of forest restoration, Perkins et al. (2012) conclude that planting trees may trigger important eco-hydrological changes to soil water properties over time. Other studies have demonstrated that plant roots, living or dead, play a role in channelling and directing the water flow through the soil, indicating the occurrence of an hydrological response to the rainfall event (SARDANS; PEÑUELAS, 2014; SIEGERT; LEVIA, 2014; ELLISON et al., 2017).

The amount of rain that reaches the soil can infiltrate or drain superficially, depending on the infiltration capacity of the soil. Commonly, the infiltration capacity of forest soils is high, resulting in small runoff rates (PAULE-MERCADO et al., 2017). However, soils with unprotected surfaces are more prone to get compacted (ALMEIDA et al., 2018), and their infiltration capacities can decrease drastically, resulting in increased surface runoff and water loss from the system (ALAOUI et al., 2017).

Compaction also reduces soil aeration, influencing infiltration and hydraulic conductivity throughout the soil layers, and can promote changes in soil chemical and biological processes (LETEY, 1985). In addition, this process decreases the availability of water and nutrients to the plants, hindering root growth. Thus, the evaluation of resistance to soil penetration is important for forest restoration analyses. Penetration resistance, root architecture and water absorption are closely related, and determine the potential for water access by plants (COLOMBI et al., 2017; COLOMBI et al., 2018).

In addition to plant cover, moisture is also related to soil resistance. When the humidity is low, soil water tension increases, which, together with the cohesive and adhesion forces of the solids present, result in a higher penetration resistance (CAMPOS; ALVES, 2006). This relationship can be observed in penetration studies that use high moisture rates to reduce the risk of elevating the penetration resistance above measurable levels (BECKET'T et al., 2018). When soils have higher water content, these forces are minimized, facilitating root development (CUNHA et al., 2002; PULIDO et al., 2017).

Soil moisture content influences surface runoff formation, plant transpiration and soil evaporation, being fundamental in the control of hydrological processes (ÁVILA et al., 2010; NEUMANN; CARDON, 2012; SACHS; SARAH, 2017; SAWAN, 2018).

Another important variable for understanding soil water dynamics is the infiltration rate. Several factors influence soil water infiltration, including soil type, which has a direct relationship with porosity and particle size (SOUZA; ALVES, 2003); soil moisture, which is inversely proportional to infiltration capacity (NEUMANN; CARDON, 2012; CLEVERLY et al., 2016); soil compaction, which is negatively correlated with permeability (SOUZA; ALVES, 2003); and vegetation cover, which attenuates erosion and compaction processes, facilitates the activity of arthropods and microorganisms, and increases soil aeration (SEIBERT; MCDONNELL, 2010; LIU et al., 2018).
In the ecological restoration of degraded areas, forest development influences rainwater capture and distribution, to make it available to the soil. Soil cover by the vegetation contributes to the processes of infiltration, percolation, and aquifer recharge. In this sense, differences among forest succession stages in relation to forest structure may also affect soil characteristics and hydrological processes (WISCHMEIER; SMITH, 1978; BERTOL et al., 2014).

Few studies analysed hydrological dynamics in areas under restoration. Also, Giglio and Kobiyama (2013) highlight that there are few studies on rainfall interception in other Brazilian environments beyond the Amazon and Atlantic Rainforest. In this way, it is difficult to determine at which point during forest development there is an effective contribution to water reserves within the soil. Therefore, understanding the relationships between rainwater and vegetation at different stages of forest development is of paramount importance, since it is from this poorly explored relationship that diverse reservoirs of groundwater and surface waters of the river basins depend on (BOSCH; HEWLETT, 1982; CHRISTOFFERSEN et al., 2014; HONDA et al., 2015; MELLO et al., 2017).

The Cerrado biome corresponds to areas that form eight of the twelve main Brazilian drainage basins, as classified by the National Council of Water Resources (LIMA; SILVA, 2008; BRASIL, 2017). It is considered a large water reservoir, denominated "cradle of waters", and plays a fundamental role in the processes of abstraction and distribution of water resources to other regions of Brazil, including contributions to the recharge of the Guarani aquifer (CARVALHO et al., 2016; HONDA, 2013; HUSSEIN, 2018).

However, the Cerrado is characterized as one of the most degraded biomes in the country, mainly due to activities aimed at cattle farming and extensive agriculture, with $55 \%$ of the total area deforested or transformed by human action (PELÁ; CASTILHO, 2010; CABRAL et al., 2015).

In this context, we evaluated whether forest restoration improves soil water conditions in a Cerrado area. Our hypothesis was that the combined effects of forest structure of the regenerated areas and associated hydrological variables influence soil physical attributes and soil moisture.

\section{MATERIALS AND METHODS}

\section{Study area}

The study was carried out in the Private Natural Heritage Reserve (PNHR) Floresta das Águas Perenes, in the municipality of Brotas, São Paulo, Brazil (latitude $22^{\circ} 11.754^{\prime} \mathrm{S}$ and longitude $\left.48^{\circ} 6.523^{\prime} \mathrm{O}\right)$. The PNHR covers an area of 809.78 ha of Cerrado biome, and the phytophysiognomies are characterized as secondary vegetation of Cerrado and Cerradão (SÃO PAULO, 2013). Pastures previously occupied the PNHR, but in the last 43 years Eucalyptus forestry. In 2006, after the harvesting of some Eucalyptus stands, the process of natural regeneration of these areas began (INTERNATIONAL PAPER, 2013).

The climate in the region, according to the classification of Köppen, is Cwa, having wet summer and dry winter, and mean annual rainfall between 1,400 and 1,500 mm (CEPAGRI, 2016). 
The predominant soil is the Quartzarenic Neosol. Monitoring of the hydrological indicators was carried out in areas encompassing two different stages of natural regeneration and a preserved area, being defined as: Initial stage - 4 years of natural regeneration after Eucalyptus cutting; Intermediate stage - 10 years of natural regeneration after Eucalyptus cutting; Advanced stage - 43 years without human interference. Within each area (stage), three 20x20 m plots were established, distant $10 \mathrm{~m}$ from each other.

\section{Vegetation structure}

In each plot, all individuals with diameter at breast height (DBH) larger than $5 \mathrm{~cm}$ were sampled, and their $\mathrm{DBH}$ and total height were recorded. For each plot, the following variables were obtained: mean DBH (cm), mean and maximum heights $(\mathrm{m})$, coefficient of variation of heights (an estimate of stratification), total basal area $\left(\mathrm{cm}^{2} / \mathrm{ha}\right.$ ) and density (ind. $\left./ \mathrm{m}^{2}\right)$, following Souza et al. (2013).

As a measure of coverage, illuminance was determined at nine random points in each plot with a digital luxmeter (Minipa, model MLM-1011), positioned one meter high from the ground. Measurements occurred between 10:00 to 12:00 AM. Absolute illuminance was also recorded in the open, with one record for each plot Relative Illuminance Index (RII) was calculated as the arithmetic mean of illuminance for each plot, divided by the absolute illuminance recorded in the open, and multiplied by 100. Tree structural measurements were obtained in January 2016, while illuminance was recorded monthly from February to September 2016.

\section{Soil indicators}

Soil water infiltration rates were determined with a Mini Disk Infiltrometer (Decagon Devices). Nine measurements were taken in each plot, where each measurement consisted of six replicates with an infiltration time of 30 seconds and adjustment of the suction rate in $2 \mathrm{~cm}$, as indicated for sandy soils. The data recorded in the field were used to calculate the hydraulic conductivity, using the method proposed by Zhang (1997). Subsequently, the data were converted to infiltration rate $(\mathrm{mm} / \mathrm{h})$, obtained by the ratio between the accumulated infiltration variation and the infiltration time variation. From the nine measurements, the mean infiltration rate was obtained for each plot.

Penetration resistance was determined with a penetrometer (Solotest), as the average of nine random points recorded in each plot to a depth of $15 \mathrm{~cm}$. The penetration resistance $(\mathrm{MPa})$ was obtained by dividing the penetration load (in kgf) by the area of the cone base $\left(\right.$ in $\left.\mathrm{cm}^{2}\right)$. As the diameter of the base of the cone was $28.4 \mathrm{~mm}$, the area of the base of the cone was $6.33 \mathrm{~cm}^{2}$.

For soil moisture, nine measurements were taken at random points in each plot, at a depth of $15 \mathrm{~cm}$. The equipment used was a temperature and humidity meter of the Aquaterr brand, model M-350, that provides humidity in percentage (0 - 100\%); mean values per plot were used. The data of moisture, infiltration, and penetration resistance were recorded simultaneously, monthly from February to September 2016.

\section{Hydrological indicators}

Net precipitation and rainfall interception were monitored from December 2015 to November 2016, totalling one year of data collection. However, only the data recorded between February and September 2016 were used for the analyses, together with soil and vegetation parameters. Hydrological data were obtained after each rain event, which was defined as the accumulated volume at the end of one or more consecutive rainy days (LORENZON et al., 2013).

The rain gauges used in the research were constructed from pipes and PVC connections, with $78.5 \mathrm{~cm}$ diameter and $20 \mathrm{~cm}$ height, corresponding to a maximum storage volume of $1.5 \mathrm{~L}$. A total of 109 rain gauges were installed, of which 12 were inside each plot of the different stages, and one was installed in the open.

The calculation of the net precipitation ( $N P$, in $\mathrm{mm}$ ) corresponds to the sum of stemflow $(S f$, in $\mathrm{mm}$ ) and throughfall ( $T$, in $\mathrm{mm}$ ), measured in each plot, according to the Equation (1).

$N P=T f+S f$

Throughfall in each area was obtained through Equation (2):

$T f=\frac{\sum_{i=1}^{n}\left[\left(V_{i} / A_{i}\right) * 10\right]}{n}$

Where $V i$ is the volume of the $i$-th rain gauge $(\mathrm{ml}) ; A i$ is the catchment area of the $i$-th rain gauge $\left(\mathrm{cm}^{2}\right)$ and $n$ is the number of rain gauges.

The quantification of stemflow was performed on all trees with circumference at breast height $(\mathrm{CBH})>15 \mathrm{~cm}$, following Honda (2013). A total of 184 trees were selected and 210 collectors were installed. The trunk drainage ducts were installed at a standard height of $1.5 \mathrm{~m}$ and produced with polyurethane foam, which has the function of conducting the water drained by the trunks to 20 liter reservoirs. To calculate Sf, Equation (3) was used:

$S f=\left(\frac{V t}{A}\right)$

Where $V t$ is the total volume $(\mathrm{L})$; and $A$ is the plot area $\left(\mathrm{m}^{2}\right)$.

Finally, rainfall interception $(R I)$ was obtained from the difference between gross precipitation $(G P)$ and net precipitation $(N P)$ at each stage, as described in Equation (4):

$R I=G P-N P$

\section{Statistical analysis}

To assess whether the combined effects of forest structure of regenerating areas and associated hydrological variables influence soil physical attributes and soil moisture, we fitted a structural equation model, considering soil moisture as the response variable using LISREL 9.3 (JÖRESKOG; SÖRBOM, 2015) (Figure 1).

Structural equation models enables to test models that include multivariate hypotheses on interdependencies among variables, using multiple equations to represent proposed causal 


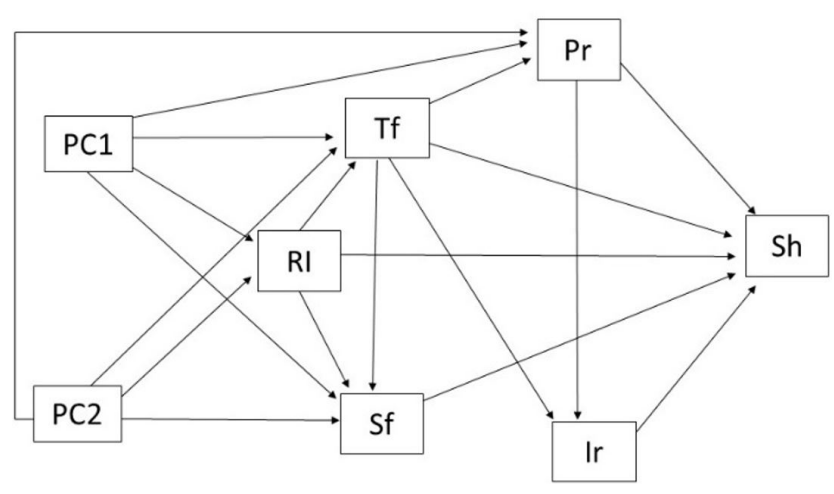

Figure 1. Proposed model showing the relationships tested among vegetation structure (PC1 and PC2), hydrological variables $(\mathrm{RI}=$ rainfall interception, $\mathrm{Sf}=$ stemflow, $\mathrm{Tf}=$ throughfall $)$ and soil water conditions $(\mathrm{Pr}=$ penetration resistance, $\mathrm{Ir}=$ infiltration rate, $\mathrm{Sh}=$ soil humidity). The lines start from the explanatory variable and point to the response variable.

relationships (GRACE, 2008). The significance of the model is tested by comparing the model-implied covariance matrix against the observed covariance matrix using the Chi-square test, being significant when $p>0.05$ (GRACE, 2008).

The data were previously compared to the normal distribution using the Shapiro-Wilk test, and only mean DBH, mean height and height $\mathrm{CV}$ had normal distributions. Basal area and maximum height were log-transformed, whereas soil compaction, infiltration rate, $T f$ and $S f$ were transformed with the Box-Cox method $(\lambda 1$ and $\lambda 2=0.1)$; density and rainfall interception were transformed using square root, and for the humidity the angular transformation was used. The RII parameter could not be transformed. Statistical analyses were performed using software R 3.1.3, with the Vegan and AID packages.

To reduce the dimensionality of vegetation structure variables, we used principal component analysis (PCA) after normalizing the variables to mean $=0$ and standard deviation $=1$. Subsequently, the scores of the first two axes of the PCA (PC1 and PC2) were used to represent the vegetation structure in the structural equations model.

\section{RESULTS}

The vegetation structure variables presented increasing values between the stages, indicating the evolution of the natural succession with the forest development. As a consequence, RII decreased from the initial to the advanced stage. The first two axes of the principal component analysis explained $94,1 \%$ of the variation in vegetation structure variables. The first axis explained $85.9 \%$ of the variation (eigenvalue $=6.01$ ), and was positively correlated with mean DBH, mean height, maximum height, height variation coefficient (CV), basal area and density, and negatively correlated with mean illuminance, so that the increase in tree height, $\mathrm{DBH}$ and basal area causes a decrease in light intensity inside the plot (Figure 2). The second axis explained only $8,2 \%$ of the variation

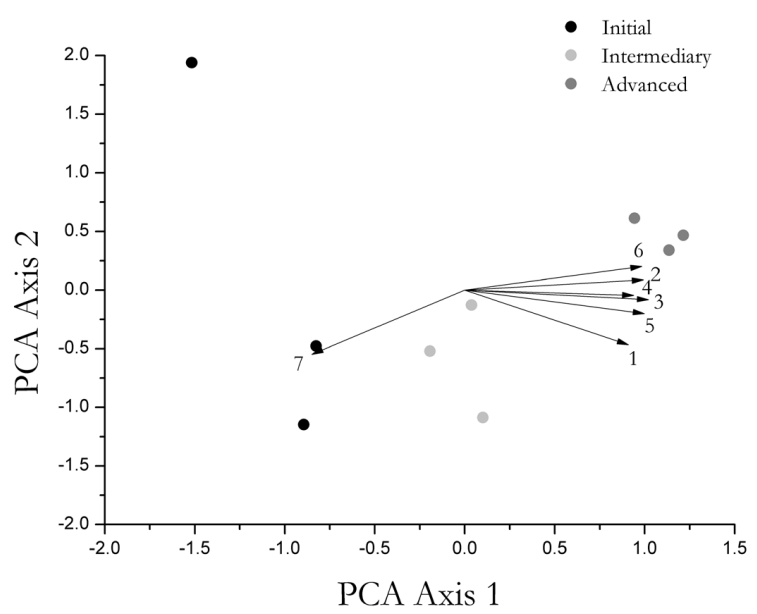

Figure 2. Principal Component Analysis ordination of plots in the Initial, Intermediate and Advanced stages, and loadings of vegetation structure variables. Numbers correspond to the vegetation structure variables: 1 - mean DBH; 2 - Mean height; 3 - Maximum height; 4 - height CV; 5 - Basal area; 6 - Density; 7 - Mean illuminance.

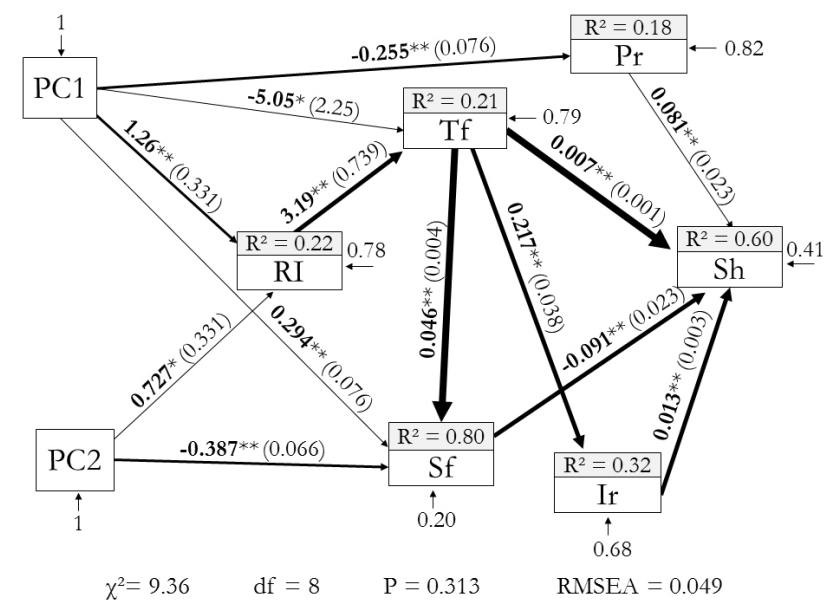

Figure 3. Fitted model showing the relationships of vegetation structure and hydrological variables in soil water conditions. The non-standard coefficient (partial regression coefficient) is in bold, followed by the standard error. The thickness of the lines are proportional to the standardized estimates. The lines start from the explanatory variable and point to the response variable. ${ }^{* *} p<0.001 ;{ }^{*} p<0.05$. Symbols as in Figure 1.

(eigenvalue $=0.576$ ), and was weakly negatively influenced by both illuminance and DBH.

The structural equations model presented a good fit to the observed data $(P=0.313)$. Only $22 \%$ of the variation in rainfall interception was explained by the vegetation structure, with stronger influence by PC1 (standardized estimate $=0.40$ ). Rainfall interception, together with PC1, explained $21 \%$ of the variation in throughfall, with stonger effect of $\mathrm{RI}($ standardized estimate $=0.52)$ than PC1 (standardized estimate $=0.26)($ Figure 3$)$. 
Regarding stemflow, $80 \%$ of its variation was explained by the first two axes of the PCA and by Tf, the latter having a greater influence on $S f$ (standardized estimate $=0.75$ ), followed by PC2 (standardized estimate $=-0.33$ ). Rainfall interception was not related to $S f$ (Figure 3). Among the variables related to soil water conditions, only $18 \%$ of the variation in resistance to soil penetration was explained by th PC1. The infiltration rate was influenced only by $\mathrm{T}$, which explained $32 \%$ of the variation.

Finally, the total effect of these variables explained $60 \%$ of the variation in soil moisture, except for rainfall interception. Tf had the largest influence (standardized estimate $=0.63$ ), followed by $S f$ (standardized estimate $=-0.52)$, infiltration rate (standardized estimate $=0.46$ ) and less influenced by soil compaction (standardized estimate $=0.28)($ Figure 3).

\section{DISCUSSION}

\section{Vegetation structure}

The first axis of the principal component analysis explained most variation in the vegetation structure data, so that higher densities of tree individuals are related to lower mean $\mathrm{DBH}$ values, and increases in tree height reduce the light intensity within the studied areas.

In fact, the more advanced stages, with higher density, presented some individuals with high $\mathrm{DBH}$ and many others with reduced DBH, reflecting the presence of young regenerating individuals in the understory (DIAS et al., 2017; MENDES et al., 2013). The larger values in mean and maximum heights in these areas contributed to greater coverage by the canopy, controlling the quantity, quality and temporal and spatial distribution of light, soil moisture conditions, humidity and air temperature and rainfall interception, aspects that were considered in the analysis.

The structural equations model enabled to test complex relationships among vegetation, hydrology, and soil. Each stage of natural succession differs in relation to the morphology of the tree individuals, influencing the hydrological processes (KLOS et al., 2014). The reception and distribution of water between hydrological compartments modulated by differences in vegetation structure, and consequently soil hydrological characteristics, are examples of this complex influence (BERTOL et al., 2014; SÁ et al., 2016).

\section{Hydrological variables}

According to the model, throughfall was negatively influenced by PC1 and positively by rainfall interception, which in turn was positively correlated with PC1. This interaction between effects shows complex vegetation effects on $T$ festimates, because in more open areas, with lower development and cover of tree vegetation, $T f$ values are higher, according to experimental results found in other systems (SUN et al., 2017). On the other hand, in areas with higher tree canopy development, rainfall interception and relationships with $T f$ may be related to rainfall characteristics. According to Ahmed et al. (2017), interception depends not only on vegetation characteristics, but also on abiotic factors such as the amount of precipitation, intensity, duration and wind direction.
In this way, intense and long-lasting rains can rapidly saturate the retention capacity of the canopy, minimizing the interception and forming of water accumulation o in the canopies zones and, consequently, drip flow (KEIM; LINK, 2018; TANAKA et al., 2017). In our study, we observed many intense rainfall events, which may have rapidly saturated the canopy, resulting in a positive correlation between $R I$ and $T f$, as predicted for these precipitation characteristics. In general, low-intensity and short-duration rains are more easily trapped in the canopies because they are not able to saturate them; in this case, the relationship between interception and throughfall should be negative, whereas when intense and prolonged rains occur, there is rapid saturation of the canopies and formation of drip points, leading to an increase in throughfall.

Stemflow was related to throughfall and to forest structure. Recent studies show interactive effects between vegetation structure and meteorological conditions (LEVIA; GERMER, 2015). The volume of $S f$ increases with the tree sizes (e.g., HONDA et al., 2015), as verified in our study in relation to PC1, but this relation may depend on characteristics of the branches such as orientation angle, diameter and density; in addition, younger trees, with lower leaf canopy development, also contribute to $S f$ increase (LEVIA; GERMER, 2015). Sf production increases when rainfall characteristics are more variable within each rainfall event than in more homogeneous events, while strong winds increase the interception and consequent $S f$ values in larger canopies (LEVIA, 2014; LEVIA; GERMER, 2015). In the same way, our study recorded events with large volumes and strong winds, factors that contributed to the faster generation of stemflow; in addition, the winds that affected the areas may have directed rain directly to the trunks, especially in higher rainfall volumes. In a tropical environment, Corrêa et al. (2016) verified the influence of the macaúba palm morphology on $S f$ estimates, also recording higher values with higher rainfall volumes.

\section{Soil variables}

The fitted model indicated that soil moisture was influenced by two hydrological variables and two soil physical variables, with indirect effects of the structure of the studied forests. Soil moisture was more strongly influenced by $T$, where the volume and intensity of the storm are important for the humidity patterns, with lower effect of the stemflow, which had a negative effect. In their study, Liang et al. (2011) evaluated the effects of stemflow on soil water dynamics. They found that $S f$ captures precipitation and channels the collected volume to the roots, influencing soil moisture patterns at greater depths, which would prevent the captured volume from moistening the soil as a whole.

We observed that the initial stage had the highest values of penetration resistance. A factor related to these results are the different management systems that can result in different values of soil compaction (Table 1), as observed in a study conducted by Bono et al. (2013). From the history of land use and occupation of the studied area, the initial stage is the youngest in the process of natural regeneration. Previously, for more than 40 years, the site was destined to the Eucalyptus plantation, being subject to periodic compaction by the machines used in the harvests. Anyway, the values obtained in our study are within the expected for Cerrado areas in 
Table 1. Mean values $( \pm$ SD) of soil and hydrological indicators for the initial, intermediate, and advanced stages of forest restoration in the PNHR Floresta das Águas Perenes, SE Brazil, from February to September 2016. Tf $=$ throughfall; $\mathrm{RI}=$ rainfall interception; Sf $=$ stemflow.

\begin{tabular}{|c|c|c|c|c|c|c|c|}
\hline \multirow{10}{*}{ 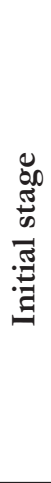 } & & $\begin{array}{c}\text { Penetration } \\
\text { resistance } \\
(\mathrm{MPa})\end{array}$ & Moisture (\%) & $\begin{array}{l}\text { Infiltration rate } \\
(\mathrm{mm} / \mathrm{h})\end{array}$ & Tf $(\mathrm{mm})$ & RI (mm) & Sf $(\mathrm{mm})$ \\
\hline & Feb. & $0.4 \pm 0.2$ & $72 \pm 7.0$ & $227.5 \pm 86.3$ & 199.1 & 0.9 & 0.029 \\
\hline & Mar. & $0.2 \pm 0.1$ & $77 \pm 11.0$ & $188.0 \pm 70.0$ & 167.9 & 1.8 & 0.016 \\
\hline & Apr. & $0.7 \pm 0.3$ & $74 \pm 11.0$ & $54.0 \pm 54.0$ & 0.0 & 0.0 & 0.000 \\
\hline & May & $0.9 \pm 0.1$ & $83 \pm 8.0$ & $200.0 \pm 132.0$ & 139.2 & 0.0 & 0.015 \\
\hline & Jun. & $0.1 \pm 0.09$ & $90 \pm 6.0$ & $92.2 \pm 105.0$ & 111.5 & 0.6 & 0.026 \\
\hline & Jul. & $0.7 \pm 0.3$ & $58 \pm 16.0$ & $194.0 \pm 304.2$ & 3.0 & 0.2 & 0.000 \\
\hline & Aug. & $0.5 \pm 0.2$ & $70 \pm 8.0$ & $106.6 \pm 54.0$ & 27.5 & 0.5 & 0.003 \\
\hline & Sep. & $0.8 \pm 0.3$ & $68 \pm 16.0$ & $39.5 \pm 33.2$ & 19.0 & 0.1 & 0.003 \\
\hline & Mean & $0.5 \pm 0.3$ & $74 \pm 11.0$ & $138.0 \pm 91.0$ & 83.4 & 0.5 & 0.011 \\
\hline \multirow{10}{*}{ 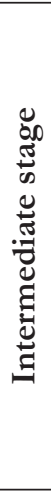 } & & $\begin{array}{c}\text { Penetration } \\
\text { resistance } \\
(\mathrm{MPa})\end{array}$ & Moisture (\%) & $\begin{array}{c}\text { Infiltration rate } \\
(\mathrm{mm} / \mathrm{h})\end{array}$ & Tf $(\mathrm{mm})$ & RI (mm) & Sf $(\mathrm{mm})$ \\
\hline & Feb. & $0.3 \pm 0.1$ & $67 \pm 13.5$ & $458.7 \pm 358.0$ & 198.6 & 1.0 & 0.431 \\
\hline & Mar. & $0.2 \pm 0.1$ & $55 \pm 33.5$ & $330.5 \pm 202.9$ & 159.3 & 10.3 & 0.217 \\
\hline & Apr. & $0.3 \pm 0.2$ & $31 \pm 7.2$ & $65.0 \pm 65.5$ & 0.0 & 0.0 & 0.000 \\
\hline & May & $0.2 \pm 0.1$ & $57 \pm 10.4$ & $226.3 \pm 154.8$ & 120.9 & 17.7 & 0.274 \\
\hline & Jun. & $0.05 \pm 0.07$ & $66 \pm 5.0$ & $190.4 \pm 321.9$ & 98.4 & 13.4 & 0.267 \\
\hline & Jul. & $0.2 \pm 0.1$ & $36 \pm 6.3$ & $14.4 \pm 8.8$ & 2.8 & 0.4 & 0.001 \\
\hline & Aug. & $0.1 \pm 0.09$ & $37 \pm 14.2$ & $134.0 \pm 99.5$ & 25.7 & 2.3 & 0.063 \\
\hline & Sep. & $0.1 \pm 0.08$ & $28 \pm 8.0$ & $32.3 \pm 30.5$ & 19.1 & 0.0 & 0.042 \\
\hline & Mean & $0.2 \pm 0.1$ & $48 \pm 17.0$ & $209.1 \pm 195.3$ & 78.1 & 5.6 & 0.162 \\
\hline \multirow{10}{*}{ 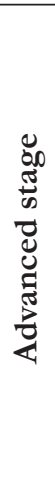 } & & $\begin{array}{c}\text { Penetration } \\
\text { resistance } \\
(\mathrm{MPa})\end{array}$ & Moisture (\%) & $\begin{array}{l}\text { Infiltration rate } \\
(\mathrm{mm} / \mathrm{h})\end{array}$ & Tf $(\mathrm{mm})$ & RI (mm) & Sf $(\mathrm{mm})$ \\
\hline & Feb. & $0.2 \pm 0.1$ & $75 \pm 2.4$ & $344.8 \pm 207.3$ & 180.5 & 182.5 & 2.049 \\
\hline & Mar. & $0.1 \pm 0.2$ & - & $295.8 \pm 106.7$ & 130.3 & 132.5 & 2.165 \\
\hline & Apr. & $0.3 \pm 0.1$ & $54 \pm 14.3$ & $10.8 \pm 0$ & 0.0 & 0.0 & 0.000 \\
\hline & May & $0.3 \pm 0.07$ & $67 \pm 6.0$ & $251.5 \pm 238.0$ & 110.8 & 112.4 & 1.603 \\
\hline & Jun. & $0.3 \pm 0.1$ & $57 \pm 10.1$ & $20.0 \pm 13.1$ & 96.2 & 97.9 & 1.653 \\
\hline & Jul. & $0.2 \pm 0.1$ & $47 \pm 7.0$ & $36.4 \pm 22.3$ & 2.2 & 2.2 & 0.008 \\
\hline & Aug. & $0.2 \pm 0.07$ & $60 \pm 6.1$ & $161.7 \pm 140.6$ & 21.1 & 21.4 & 0.340 \\
\hline & Sep. & $0.1 \pm 0.06$ & $41 \pm 11.0$ & $58.2 \pm 78.0$ & 16.7 & 17.0 & 0.306 \\
\hline & Mean & $0.2 \pm 0.1$ & $57 \pm 11.3$ & $176.6 \pm 151.7$ & 69.7 & 13.1 & 1.015 \\
\hline
\end{tabular}

a natural regeneration process. Beutler et al. (2001), for example, studying a Cerrado area and four other management systems, found that the soil under native vegetation had lower resistivity (0.2 MPa) than the others (<1.4 MPa). Campos and Alves (2006) also studied areas of native Cerrado vegetation and both areas with advanced degradation and regeneration after planting, and obtained lower values penetration resistance in native vegetation (0.72 $\mathrm{MPa})$, followed by the regenerating area $(2.38 \mathrm{MPa})$ and higher values ni the area under advanced degradation (5.92 MPa).

In the structural equations model, soil penetration resistance was weakly related to the studied variables. However, it was related with PC1, showing that vegetation development and tree growth in restoration areas may actually contribute to the reduction of penetration resistance, reflecting the ability of the vegetation to improve soil quality. Price et al. (2010), for example, studied soils from forested areas compared to grazing soils and lawns. The authors found significantly lower mass density in forest soils than in other uses, as well as infiltration rates and higher water retention capacities. These differences in the hydraulic properties of the forest and non-forest soils were attributed to the compaction associated to the land management practices (PRICE et al., 2010). Other studies also found a similar relationship corroborating these results (NIJZINK et al., 2016; PERKINS et al., 2012).

The infiltration rate is influenced positively by throughfall and this, in turn, influences soil moisture (Figure 3). Thus, raindrops that cross the canopy and reach the ground through throughfall moistens the first soil layers and is rapidly infiltrated. Coenders-Gerrits et al. (2013) showed that the pattern of throughfall is more important during large storms and especially on gentle slopes. In this way, increased throughfall intensifies infiltration rates, and $S f$ is a good predictor of the amount of rainfall that will definitely infiltrate (FORSYTHE, 1975). Both parameters, moisture and infiltration rates, are related, showing that soil modifications due to changes in land use are significant factors in hydrological changes. 


\section{CONCLUSIONS}

In this study, we evaluated whether Cerrado areas in different stages of natural regeneration are able to promote the improvement of soil water conditions. We used a structural equations model that allowed to evaluate the direct and indirect relationships between variables of vegetation structure, hydrological indicators and soil attributes.

In general, vegetation attributes evaluated at each stage of succession (4, 9 and 43 years) affect the hydrological variables by influencing the volumes intercepted by the canopies, and the amounts of throughfall and stemflow. In addition to the structural characteristics of each stage, rainfall characteristics, such as intensity, duration and the occurrence of strong winds, are also capable of influencing hydrological indicators. The positive relationship between throughfall and interception is an example of the performance of these factors. Therefore, more detailed monitoring of hydrological indicators is recommended in order to eliminate any possibility of incoherence in the analyses.

The present study found that indirect effects of vegetation on soil variables through hydrological variables can contribute to the availability of water to the root systems and replenishment of water in the soil. Thus, we recommend studies that deepen knowledge about the interaction between vegetation, hydrology and soil characteristics, to better understand the processes involved in the restoration of degraded areas, and also how these processes influence ecosystem functions.

\section{ACKNOWLEDGEMENTS}

To Coordenação de Aperfeiçoamento de Pessoal de Nível Superior (CAPES); the Conselho Nacional de Desenvolvimento Científico e Tecnológico (CNPq); the International Paper do Brasil; Gustavo Galetti; the research group on Hydrology in Forest Ecosystems (Hidrolef): Alexandra Guidelli Rosa and Matheus Bruckner; and Andréa L.T. Souza for help in statistical analysis.

\section{REFERENCES}

AHMED, A.; TOMAR, J. M. S.; MEHTA, H.; KAUSHAL, R. DEBYENDU D. E. B; CHATURVEDI, O. P.; MISHRA, P. K. Throughfall, stemflow and interception loss in grewia optiva and morus alba in North West Himalayas. Tropical Ecology, v. 58, n. 3, p. 507-514, 2017.

ALAOUI, A.; ROGGER, M.; PETH, S.; BLÖSCHL, G. Does soil compaction increase floods? A review. Journal of Hydrology, v. 557, p. 631-642, 2017. http://dx.doi.org/10.1016/j.jhydrol.2017.12.052.

ALMEIDA, W. S.; PANACHUKI, E.; OLIVEIRA, P. T. S.; MENEZES, R. S.; ALVES SOBRINHO, T. A.; CARVALHO, D. F.. Effect of soil tillage and vegetal cover on soil water infiltration. Soil \& Tillage Research, v. 175, p. 130-138, 2018. http://dx.doi. org/10.1016/j.still.2017.07.009.

ÁVILA, L. F.; MELLO, C. R.; SILVA, A. M. Continuidade e distribuição espacial da umidade do solo em bacia hidrográfica da Serra da Mantiqueira. Revista Brasileira de Engenharia Agrícola e Ambiental, v. 14, n. 35, p. 1257-1266, 2010. http://dx.doi. org/10.1590/S1415-43662010001200002.

BECKETT, C. T. S.; BEWSHER, S.; GUZZOMI, A. L.; LEHANE, B. M.; FOURIE, A. B.; RIETHMULLER, G. Evaluation of the dynamic cone penetrometer to detect compaction in ripped soils. Soil \& Tillage Research, v. 175, p. 150-157, 2018. http://dx.doi. org/10.1016/j.still.2017.09.009.

BERTOL, I.; RAMOS, R. R.; BARBOSA, F. T.; RAMOS, J. C.; BANDEIRA, D. H.; TANAKA, M. S. Hydrological processes obtained on the plot scale under four simulated rainfall tests during the cycle of different crop systems. Revista Brasileira de Ciência do Solo, v. 38, n. 2, p. 599-607, 2014. http://dx.doi.org/10.1590/ S0100-06832014000200024.

BEUTLER, A. N.; SILVA, M. L. N.; CURI, N.; FERREIRA, M. M.; CRUZ, J. C.; PEREIRA FILHO, I. A. Resistência à penetração $\mathrm{e}$ permeabilidade de latossolo vermelho distrófico típico sob sistemas de manejo na região dos cerrados. Revista Brasileira de Ciência do Solo, v. 25, n. 1, p. 167-177, 2001. http://dx.doi.org/10.1590/ S0100-06832001000100018.

BONO, J. A. M.; MACEDO, M. C. M.; TORMENA, C. A. Qualidade física do solo em um latossolo vermelho da região sudoeste dos cerrados sob diferentes sistemas de uso e manejo. Revista Brasileira de Ciência do Solo, v. 37, n. 3, p. 743-753, 2013. http://dx.doi.org/10.1590/S0100-06832013000300021.

BOSCH, J. M.; HEWLETTT, J. D. A review of catchment experiments to determine the effect of vegetation changes on water yield and evapotranspiration. Journal of Hydrology (Amsterdam), v. 55, n. 1-4, p. 3-23, 1982. https://doi.org/10.1016/0022-1694(82)90117-2.

BRASIL. O bioma Cerrado. Brasília: Ministério do Meio Ambiente, 2017. Disponível em: <http://www.mma.gov.br/biomas/cerrado>. Acesso em: 04 dez. 2017.

BROGNA, D.; DUFRÊNE, M.; MICHEZ, A.; LATLI, A.; JACOBS, S.; VINCKE, C.; DENDONCKER, N. Forest cover correlates with good biological water quality. Insights from a regional study (Wallonia, Belgium). Journal of Environmental Management, v. 211, p. 9-21, 2018. http://dx.doi.org/10.1016/j.jenvman.2018.01.017. PMid:29408087.

CABRAL, O. M. R.; DA ROCHA, H. R.; GASH, J. H.; FREITAS, H. C.; LIGO, M. A. V. Water and energy fluxes from a woodland savanna (cerrado) in southeast Brazil. Journal of Hydrology: Regional Studies, v. 4, p. 22-40, 2015. https://doi.org/10.1016/j. ejrh.2015.04.010.

CAMPOS, F. D. S.; ALVES, M. C. Resistência à penetração de um solo em recuperação sob sistemas agrossilvopastoris. Revista Brasileira de Engenharia Agrícola e Ambiental, v. 10, n. 3, p. 759-764, 2006. http://dx.doi.org/10.1590/S1415-43662006000300032.

CARVALHO, A. P. V.; DIAS, H. C. T.; TONELLO, K. C.; PAIVA, H. N. Net precipitation and recharge of groundwater in riacho 
fundo watershed, Felixlândia-MG. Revista Árvore, v. 40, n. 6, p. 965971, 2016. http://dx.doi.org/10.1590/0100-67622016000600001.

\section{CEPAGRI - CENTRO DE PESQUISAS METEOROLÓGICAS} E CLIMÁTICAS APLICADAS A AGRICULTURA. Dados meteorológicos. Campinas: CPA, 2016. Disponível em: <http:// www.cpa.unicamp.br/index.html>. Acesso em 23 de mai. 2016.

CHRISTOFFERSEN, B. O.; RESTREPO-COUPE, N.; ARAIN, M. A.; BAKER, I. T.; CESTARO, B. P.; CIAIS, P.; FISHER, J. B.; GALBRAITH, D.; GUAN, X.; GULDEN, L.; VAN DEN HURK, B.; ICHII, K.; IMBUZEIRO, H.; JAIN, A.; LEVINE, N.; MIGUEZ-MACHO, G.; POULTER, B.; ROBERTI, D. R.; SAKAGUCHI, K.; SAHOO, A.; SCHAEFER, K.; SHI, M.; VERBEECK, H.; YANG, Z.-L.; ARAÚJO, A. C.; KRUIJT, B.; MANZI, A. O.; DA ROCHA, H. R.; VON RANDOW, C.; MUZA, M. N.; BORAK, J.; COSTA, M. H.; GONÇALVES DE GONÇALVES, L. G.; ZENG, X.; SALESKA, S. R. Mechanisms of water supply and vegetation demand govern the seasonality and magnitude of evapotranspiration in Amazonia and Cerrado. Agricultural and Forest Meteorology, v. 191, p. 33-50, 2014. http:// dx.doi.org/10.1016/j.agrformet.2014.02.008.

CLEVERLY, J.; EAMUS, D.; RESTREPO COUPE, N.; CHEN, C.; MAES, W.; LI, L.; FAUX, R.; SANTINI, N. S.; RUMMAN, R.; YU, Q.; HUETE, A. Soil moisture controls on phenology and productivity in a semi-arid critical zone. The Science of the Total Environment, v. 568, p. 1227-1237, 2016. http://dx.doi.org/10.1016/j. scitotenv.2016.05.142. PMid:27241203.

COENDERS-GERRITS, A. M. J.; HOPP, L.; SAVENIJE, H. H. G.; PFISTER, L. The effect of spatial throughfall patterns on soil moisture patterns at the hillslope scale. Hydrology and Earth System Sciences, v. 17, n. 5, p. 1749-1763, 2013. http://dx.doi.org/10.5194/ hess-17-1749-2013.

COLOMBI, T.; KIRCHGESSNER, N.; WALTER, A.; KELLER, T. Root tip shape governs root elongation rate under increased soil strength. Plant Physiology, v. 174, n. 4, p. 2289-2301, 2017. http:/ / dx.doi.org/10.1104/pp.17.00357. PMid:28600344.

COLOMBI, T.; TORRES, L. C.; WALTER, A.; KELLER, T. Feedbacks between soil penetration resistance, root architecture and water uptake limit water accessibility and crop growth - a vicious circle. The Science of the Total Environment, v. 626, p. 10261035, 2018. http://dx.doi.org/10.1016/j.scitotenv.2018.01.129. PMid:29898511.

CORRÊA, J. B. L.; DIAS, H. C. T.; SATO, A. Y.; TONELLO, K. C.; FERRAZ, A. G.; FERREIRA, F. M. The influence of the number of leaves in the macaúba palm Acrocomia aculeata (Jacq.) Lodd. ex Mart. on the correlation between stemflow and gross precipitation. Revista Árvore, v. 40, n. 3, p. 387-393, 2016. http:// dx.doi.org/10.1590/0100-67622016000300002.

CUNHA, J. P. A. R.; VIEIRA, L. B.; MAGALHÃES, A. C. Resistência mecânica do solo à penetração sob diferentes densidades e teores de água. Engenharia na Agricultura, v. 10, n. 1-4, p. 1-7, 2002.
DIAS, D. D. M.; PAGOT'TO, M. A.; PEREIRA, T. C.; RIBEIRO, A. D. S. Estrutura arbórea e sazonalidade da cobertura do dossel em vegetação florestada e aberta no parque nacional serra de Itabaiana, Sergipe, Brasil. Ciência Florestal, v. 27, n. 2, p. 719-732, 2017. http://dx.doi.org/10.5902/1980509827757.

ELLISON, D.; MORRIS, C. E.; LOCATELLI, B.; SHEIL, D.; COHEN, J.; MURDIYARSO, D.; GUTIERREZ, V.; NOORDWIJK, M.; CREED, I. F.; POKORNY, J.; GAVEAU, D.; SPRACKLEN, D. V.; TOBELLA, A. B.; ILSTEDT, U.; TEULING, A. J.; GEBREHIWOT, S. G.; SANDS, D. C.; MUYS, B.; VERBIST, B.; SPRINGGAY, E.; SUGANDI, Y.; SULLIVAN, C. A. Trees, forests and water: Cool insights for a hot world. Global Environmental Change, v. 43, p. 51-61, 2017. http://dx.doi.org/10.1016/j.gloenvcha.2017.01.002.

FAO - FOOD AND AGRICULTURE ORGANIZATION OF THE UNITED NATIONS. Forests and water: international momentum and action. Rome: FAO, 2013.

FORSYTHE, W. Fisica de suelos: manual de laboratório. San Jose: Instituto Interamericano de Ciências Agrícolas, 1975.

GIGLIO, J. N.; KOBIYAMA, M. Interceptação da chuva: uma revisão com ênfase no monitoramento em florestas brasileiras. Revista Brasileira de Recursos Hídricos, v. 18, n. 2, p. 297-317, 2013. http://dx.doi.org/10.21168/rbrh.v18n2.p297-317.

GRACE, J. B. Structural equation modeling for observational studies. The Journal of Wildlife Management, v. 72, n. 1, p. 14-22, 2008. http://dx.doi.org/10.2193/2007-307.

HONDA, E. A. Repartição da água da chuva sob o dossel e umidade do solo no gradiente fisionômico da vegetação do Cerrado. 2013. 189 f. Tese (Doutorado em Ciências da Engenharia Ambiental) - Escola de Engenharia de São Carlos da Universidade de São Paulo, São Carlos, 2013.

HONDA, E. A.; MENDONÇA, A. H.; DURIGAN, G. Factors affecting the stemflow of trees in the Brazilian Cerrado. Ecohydrology, v. 8, n. 7, p. 1351-1362, 2015. http://dx.doi.org/10.1002/eco.1587.

HUSSEIN, H. The guarani aquifer system, highly present but not high profile: a hydropolitical analysis of transboundary groundwater governance. Environmental Science \& Policy, v. 83, n. 83, p. 54-62, 2018. http://dx.doi.org/10.1016/j.envsci.2018.02.005.

INTERNATIONAL PAPER. Plano de manejo. Memphis: International Paper, 2013. Versão DPA 002-6.

JÖRESKOG, K. G.; SÖRBOM, D. LISREL 9.20 for windows. Skokie: Scientific Software International Inc, 2015. Computer software.

KEIM, R. F.; LINK, T. E. Linked spatial variability of throughfall amount and intensity during rainfall in a coniferous forest. Agricultural and Forest Meteorology, v. 248, p. 15-21, 2018. http:// dx.doi.org/10.1016/j.agrformet.2017.09.006. 
KLOS, P. Z.; CHAIN-GUADARRAMA, A.; LINK, T. E.; FINEGAN, B.; VIERLING, L. A.; CHAZDON, R. Throughfall heterogeneity in tropical forested landscapes as a focal mechanism for deep percolation. Journal of Hydrology, v. 519, p. 2180-2188, 2014. http://dx.doi.org/10.1016/j.jhydrol.2014.10.004.

LETEY, J. Relationship between soil physical properties and crop production. In: STEWART, B. A. (eds). Advances in soil science. New York: Springer, 1985. p. 277-94. (Soil, v. 1). https://doi. org/10.1007/978-1-4612-5046-3_8.

LEVIA, D. F. Differential winter stemflow generation under contrasting storm conditions in a southern New England broadleaved deciduous forest. Hydrological Processes, v. 18, n. 6, p. 1105-1112, 2014. http://dx.doi.org/10.1002/hyp.5512.

LEVIA, D. F; GERMER, S. A review of stemflow generation dynamics and stemflow-environment interactions in forests and shrublands. Reviews of Geophysics, v. 53, n. 3, p. 673-714, 2015. http://dx.doi.org/10.1002/2015RG000479.

LIANG, W. L.; KOSUGI, K.; MIZUYAMA, T. Soil water dynamics around a tree on a hillslope with or without rainwater supplied by stemflow. Water Resources Research, v. 47, n. 2, p. W02541, 2011. https://doi.org/10.1029/2010WR009856.

LIMA, J. E. F. W.; SILVA, E. M. Análise da situação dos recursos hídricos do Cerrado com base na importância econômica e socioambiental de suas águas. In: IX SIMPÓSIO NACIONAL DO CERRADO, 9., 12-17 out. 2008, Brasília. Anais..., 2008. Planaltina: Embrapa Cerrados. CD-ROM.

LIU,Z.;JIA, G.; YU, X.; LU, W.; ZHANG, J. Water use by broadleaved tree species in response to changes in precipitation in a mountainous area of Beijing. Agriculture, Ecosystems \& Environment, v. 251, p. 132-140, 2018. http://dx.doi.org/10.1016/j.agee.2017.09.021.

LORENZON, A. S.; DIAS, H. C. T.; LEITE, H. G. Precipitação efetiva e interceptação da chuva em um fragmento florestal com diferentes estágios de regeneração. Revista Árvore, v. 37, n. 4, p. 619627, 2013. http://dx.doi.org/10.1590/S0100-67622013000400005.

LUO, P.; ZHOU, M.; DENG, H.; LYU, J.; CAO, W.; TAKARA, K.; NOVER, D.; GEOFFREY SCHLADOW, S. Impact of forest maintenance on water shortages: Hydrologic modeling and effects of climate change. The Science of the Total Environment, v. 615, p. 1355-1363, 2018. http://dx.doi.org/10.1016/j.scitotenv.2017.09.044. PMid:29751440.

MELLO, K.; RANDHIR, T. O.; VALENTE, R. A.; VETTORAZZI, C. A. Riparian restoration for protecting water quality in tropical agricultural watersheds. Ecological Engineering, v. 108, p. 514-524, 2017. http://dx.doi.org/10.1016/j.ecoleng.2017.06.049.

MENDES, F. D. S.; JARDIM, F. C. S.; CARVALHO, J. O. P.; SOUZA, D. V.; ARAÚJO, C. B.; OLIVEIRA, M. G.; LEAL, E. D. S.. Dinâmica da estrutura da vegetação do sub-bosque sob influência da exploração em uma floresta de terra firme no município de moju - PA. Ciência Florestal, v. 23, n. 2, p. 379-391, 2013. http://dx.doi.org/10.5902/198050989283.

NEUMANN, R. B.; CARDON, Z. G. The magnitude of hydraulic redistribution by plant roots: a review and synthesis of empirical and modeling studies. The New Phytologist, v. 194, n. 2, p. 337-352, 2012. http://dx.doi.org/10.1111/j.1469-8137.2012.04088.x. PMid:22417121.

NIJZINK, R.; HUTTON, C.; PECHLIVANIDIS, I.; CAPELL, R.; ARHEIMER, B.; FREER, J.; HAN, D.; WAGENER, T.; MCGUIRE, K.; SAVENIJE, H.; HRACHOWITZ, M. The evolution of root-zone moisture capacities after deforestation: A step towards hydrological predictions under change? Hydrology and Earth System Sciences, v. 20, n. 12, p. 4775-4799, 2016. http:// dx.doi.org/10.5194/hess-20-4775-2016.

PAULE-MERCADO, M. A.; LEE, B. Y.; MEMON, S. A.; UMER, S. R.; SALIM, I.; LEE, C. H. Influence of land development on stormwater runoff from a mixed land use and land cover catchment. The Science of the Total Environment, v. 599-600, p. 2142-2155, 2017. http://dx.doi.org/10.1016/j.scitotenv.2017.05.081. PMid:28575929.

PELÁ, M.; CASTILHO, D. Cerrados: perspectivas e olhares. Goiânia: Editora Vieira, 2010. 182 p.

PERKINS, K. S.; NIMMO, J. R.; MEDEIROS, A. C. Effects of native forest restoration on soil hydraulic properties, Auwahi, Maui, Hawaiian Islands. Geophysical Research Letters, v. 39, n. 5, p. 2-5, 2012. http://dx.doi.org/10.1029/2012GL051120.

PRICE, K.; JACKSON, C. R.; PARKER, A. J. Variation of surficial soil hydraulic properties across land uses in the southern Blue Ridge Mountains, North Carolina, USA. Journal of Hydrology, v. 383, n. 3-4, p. 256-268, 2010. http://dx.doi.org/10.1016/j. jhydrol.2009.12.041.

PULIDO, M.; SCHNABEL, S.; CONTADOR, J. F. L.; LOZANOPARRA, J.; GÓMEZ-GUTIÉRREZ, Á.; BREVIK, E. C.; CERDÀ, A. Reduction of the frequency of herbaceous roots as an effect of soil compaction induced by heavy grazing in rangelands of SW Spain. Catena, v. 158, p. 381-389, 2017. http://dx.doi.org/10.1016/j. catena.2017.07.019.

SÁ, J. H. M.; CHAFFE, P. L. B.; QUILLET, M. J. J. The influence of the interception process on the precipitation quality in a catchment covered by subtropical Atlantic Forest. Revista Brasileira de Recursos Hídricos, v. 21, n. 4, p. 742-751, 2016. http://dx.doi. org/10.1590/2318-0331.011616045.

SACHS, E.; SARAH, P. Combined effect of rain temperature and antecedent soil moisture on runoff and erosion on Loess. Catena, v. 158, n. 158, p. 213-218, 2017. http://dx.doi.org/10.1016/j. catena.2017.07.007.

SÃO PAULO. RPPN SP/2013: anuário das reservas particulares do patrimônio natural instituídas pela Secretaria do Meio Ambiente do Estado de São Paulo. São Paulo: Secretaria do Meio Ambiente, 
2013. Disponível em: <www.ambiente.gov.sp.br>. Acesso em: 15 jun. 2016.

SARDANS, J.; PEÑUELAS, J. Hydraulic redistribution by plants and nutrient stoichiometry: shifts under global change. Ecohydrology, v. 7, n. 1, p. 1-20, 2014. http://dx.doi.org/10.1002/eco.1459.

SAWAN, Z. M. Climatic variables: evaporation, sunshine, relative humidity, soil and air temperature and its adverse effects on cotton production. Information Processing in Agriculture, v. 5, n. 1, p. 134-148, 2018. http://dx.doi.org/10.1016/j.inpa.2017.09.006.

SEIBERT, J.; MCDONNELL, J. J. Land-cover impacts on streamflow: a change-detection modelling approach that incorporates parameter uncertainty. Hydrological Sciences Journal, v. 55, n. 3, p. 316-332, 2010. http://dx.doi.org/10.1080/02626661003683264.

SIEGERT, C. M.; LEVIA, D. F. Seasonal and meteorological effects on differential stemflow funneling ratios for two deciduous tree species. Journal of Hydrology, v. 519, p. 446-454, 2014. http:/ / dx.doi.org/10.1016/j.jhydrol.2014.07.038.

SOUZA, A. L. T.; FONSECA, D. G.; LIBÓRIO, R. A.; TANAKA, $\mathrm{M}$. O. Influence of riparian vegetation and forest structure on the water quality of rural low-order streams in SE Brazil. Forest Ecology and Management, v. 298, p. 12-18, 2013. http://dx.doi. org/10.1016/j.foreco.2013.02.022.

SOUZA, Z. M.; ALVES, M. C. Movimento de água e resistência à penetração em um Latossolo Vermelho distrófico de cerrado, sob diferentes usos e manejos. Revista Brasileira de Engenharia Agrícola e Ambiental, v. 7, n. 1, p. 18-23, 2003. http://dx.doi.org/10.1590/ S1415-43662003000100004.

SUN, X.; ONDA, Y.; KATO, H.; GOMI, T.; LIU, X. Estimation of throughfall with changing stand structures for Japanese cypress and cedar plantations. Forest Ecology and Management, v. 402, p. 145-156, 2017. http://dx.doi.org/10.1016/j.foreco.2017.07.036.

TANAKA, N.; LEVIA, D.; IGARASHI, Y.; YOSHIFUJI, N.; TANAKA, K.; TANTASIRIN, C.; NANKO, K.; SUZUKI, M.; KUMAGAI, T. What factors are most influential in governing stemflow production from plantation-grown teak trees? Journal of Hydrology, v. 544, p. 10-20, 2017. http://dx.doi.org/10.1016/j. jhydrol.2016.11.010.

WISCHMEIER, W.H., SMITH, D.D. Predicting rainfall erosion losses: a guide to conservation planning. Washington: USDA, 1978.

ZHANG, R. Determination of soil sorptivity and hydraulic conductivity from the disk infiltrometer. Soil Science Society of America Journal, v. 61, n. 4, p. 1024-1103, 1997. http://dx.doi. org/10.2136/sssaj1997.03615995006100040005x.

ZHANG, Y.; WANG, X.; HU, R.; PAN, Y. Stemflow volume per unit rainfall as a good variable to determine the relationship between stemflow amount and morphological metrics of shrubs. Journal of Arid Environments, v. 141, p. 1-6, 2017. http://dx.doi. org/10.1016/j.jaridenv.2017.02.002.

\section{Authors contributions}

Débora Bessi: Contribution in the paper conception, participated in the field (installation of equipment, measurement and monitoring of indicators), bibliographical research, data analysis and interpretation of results, writing, preparation of figures and tables, revision of the manuscript.

Marcel Okamoto Tanaka: Methodology for data analysis, data analysis and interpretation of results, preparation of figures, writing and review of the manuscript.

Lara Aranha da Costa: Participated in the field (installation of equipment, measurement and monitoring of indicators), data analysis.

Carina Julia Pensa Correa: Bibliographical research, revision of the manuscript.

Kelly Cristina Tonello: Research coordinator, paper conception, participated in the field (installation of equipment, measurement and monitoring of indicators), writing. CNPQ Productivity Grant. 